\title{
Laboratory rearing of barnacle larvae for antifouling research
}

\author{
D. J. Tighe-Ford, M. J. D. Power and D. C. Vaile \\ Exposure Trials Station, Central Dockyard Laboratory; \\ Portsmouth, Great Britain
}

\begin{abstract}
KURZFASSUNG: Laboratoriumszucht von Seepockenlarven für „Antifouling“-Untersuchungen. Es wird eine Methode beschrieben für die Massenzucht von Larven des Cirripediers Elminius modestus. Die produzierten Larven sind für Toxizitätstests und Verhaltensstudien vorgesehen. Populationen von 5000 bis 10000 Nauplien werden in 4-Liter-Gefäßen bei konstanter Wassertemperatur erbrütet. Antibiotika und Diatomeen werden dem Seewasser (Kulturmedium), welches häufig erneuert wird, hinzugefügt. Die Entwicklung bis zum Cypris-Stadium dauert etwa 7 Tage; die Festheftung der Larven erfolgt 3 Tage später. Erwa 25 bis $50 \%$ der Larven überlebt und metamorphosiert normal; die jungen Adulti wachsen unter Laboratoriumsbedingungen heran. Die kontinuierliche Kultureinheit, mit der große Mengen der Diatomee Skeletonema costatum für Futterzwecke produziert werden, wird beschrieben. Es werden ferner Ergebnisse vorgelegt über die Larvalentwicklung mit besonderer Berücksichtigung von Überlebensrate, Größenzunahme und Entwicklungsgeschwindigkeit. Die Einflüsse von Licht, Diatomeenart und Individuenkonzentration, Antibiotika, Ultraviolett-Sterilisation und Temperatur werden erörtert. Die Temperatur beeinflußt nicht nur die Überlebenschancen und die Entwicklungsgeschwindigkeiten, sondern auch die Größe der Larvenstadien: Larven, welche bei niedrigen Temperaturen gezüchtet werden, sind größer als die bei hohen Temperaturen gehaltenen. Die Lichtbedingungen beeinflussen offenbar die maximal möglichen Populationsdichten der Larven. Hohe Uberlebensraten und gutes Wachstum junger Adulti wurden sowohl in stagnierendem als auch im fließenden Meerwasser erhalten. Die Versuchstiere wachsen jedoch in fließendem Meerwasser besser.
\end{abstract}

\section{INTRODUCTION}

The programme of antifouling studies at the Exposure Trials Station includes two broad areas of barnacle research; these are the testing of the effectiveness of toxic compounds of potential use in antifouling systems and investigations into the biological mechanisms controlling larval development and growth of the young adult. It is, therefore, necessary to maintain a continuous supply of nauplii and cyprids for experimental use.

The life cycle of barnacles consists of seven free-swimming larval stages (Fig. 1) and a sedentary adult stage enclosed in a calcareous shell. The eggs produced within the shell of the adult hatch as the first naupliar stage which develops through five further stages, each being larger and more complex than the preceeding one. The 
stage VI nauplius metamorphoses into the cypris, which after a period of time settles and undergoes the final metamorphosis into the young adult barnacle.

Large numbers of barnacle larvae and newly settled adults are required throughout the year. They are reared in the laboratory as it is not possible to rely on
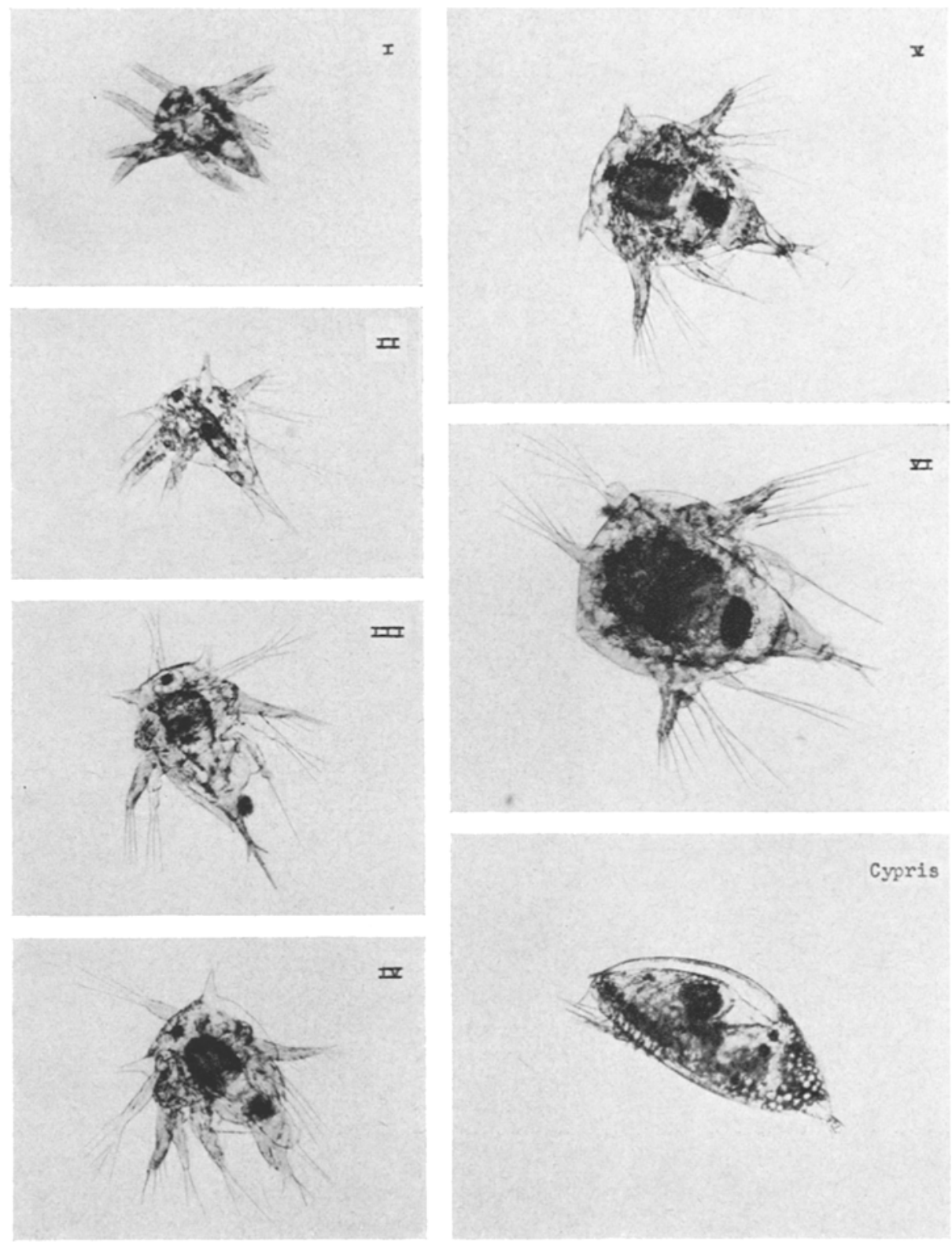

Figure 1: Larval stages of the barnacle Elminius modestus DAR wIN. $(63,5: 1)$ 
natural supplies because of the seasonal occurrence of the species and the difficulty of sorting them from the plankton.

BAssindale (1936) reared small numbers of larvae of Balanus balanoides, Chthamalus stellatus and Verruca stroemia but reported high mortalities in these species. Costlow \& Bookночт $(1957,1958)$, working with Balanus eburneus and $B$. amphitrite var. denticulata, used techniques which were not suitable to mass rearing. Moyse (1960), on the other hand, reported high survival rates through to the cypris and settled stages in beakers of unchanged sea water; a method which met with little success under our conditions due to heavy bacterial contaminations. WISELY (1960) described a flowing sea water system in which diatoms and sea water were continuously added to the rearing vessels. The low survival rates reported and the considerable risk of bacterial build-up on the walls of the rearing vessels mitigated against the use of this method. Fremberger \& Cologer (1966) developed a technique in which the larvae were filtered off daily and returned to cleaned beakers with fresh sea water and new food.

Our experiments show that, although the vessel walls are kept free of bacteria by this technique, the filters retain a proportion of the food and faeces and that consequently bacterial populations build up in the sea water. FreIberger \& Cologer (1966) did not use antibiotics and Moyse (1960) reported that their addition did not increase survival. WISELY (1960) suggested that at higher concentrations they might have an adverse effect by reducing beneficial flagellates and bacteria. However, it was found in the present study, that the addition of antibiotics virtually eliminated bacterial growth and increased the survival rate of the larvae.

To obtain successful development of barnacle larvae the food supply in the sea water has to be augmented. Previous workers have used a variety of plant and animal species for this purpose, the commonest being the diatoms Phaeodactylum tricornutum, Cyclotella nana, Skeletonema costatum and species of Coscinodiscus and Biddulphia. The most suitable food for each species of barnacle has to be determined experimentally. Moyse (1963) compared the food values of different algae for a number of barnacle species and concluded that the larvae of Elminius modestus, the major species in this study, could be reared on both flagellates and diatoms, in particular the diatom Skeletonema costatum.

Elminius modestus DARWIN, a common intertidal barnacle in Langstone Harbour was chosen as the experimental species. Although development of the larvae occurs in nature in the late spring, summer and early autumn a small percentage of adults bear egg-masses throughout the winter. A similar technique is used to rear the larvae of Balanus balanoides (L.) at $10^{\circ} \mathrm{C}$.

\section{LABORATORY REARING TECHNIQUE}

The basic requirements for rearing larvae are, a supply of sea water, a facility for controlling the temperature, a supplementary food source and a technique for handling larvae from the egg-mass to the young adult. 


\section{Sea water system}

Sea water is pumped to the laboratory through a system which is made from or lined with inert materials. There is provision for ultra-violet sterilization of the sea water and its temperature can be controlled within the range of approximately $0^{0}$ to $23^{\circ} \mathrm{C}$. By this means a variety of experimental conditions can be obtained, enabling larvae of both winter and summer breeding barnacles to be reared under optimum conditions throughout the year.

\section{Food cultures}

Diatoms of the species Skeletonema costatum (GREville) Cleve are maintained in mass-culture as a supplementary food source for the larvae. The culture unit is a modification of the one described by TrGHE-FORD (1967a) and normally produces up to 201 of food per day. The feeding concentration is maintained at 1 to $2 \times 10^{6}$ cells $/ \mathrm{ml}$ by either providing extra light from the unit for growth of the diatoms or by diluting with fresh medium when they become too dense. The cultures are continuously aerated to keep the diatoms in suspension and to supply $\mathrm{CO}_{2}$ for photosynthesis. Stirring of the cultures has been found to be unnecessary provided the rate of aeration is high.

\section{REARING OF LARVAL POPULATIONS}

\section{Collection}

Adult Elminitus modestus are scraped from rocks and jetties and placed in a 51 glass tank in the laboratory. Sea water at ambient sea temperature is added and a light shone through one corner of the tank just below the water line.

The positively phototropic stage I nauplii hatch out from the egg-masses and collect in the conner of the tank. These nauplii are pipetted off at intervals into a 11 beaker of sea water; only those that collect at the light source within 30 min are used for rearing. An estimation of the number collected is made by sampling from the beaker.

\section{Rearing conditions}

The larvae are reared in batches of 5,000 to 10,000 in 41 beakers. These "rearing beakers" contain $1,000 \mathrm{ml}$ of diatom culture at a concentration of approximately $2 \times 10^{6} \mathrm{cell} / \mathrm{ml}$ (or the equivalent volume) and $2750 \mathrm{ml}$ of unfiltered UV sterilized sea water at ambient sea temperature. After the nauplii have been put into the beakers $0.4 \mathrm{ml}$ of a Crystamycin* (Glaxo Labs) solution is added. Black tape is attached to

* This antibiotic solution contains $300 \mathrm{mg}$ sodium penicillin $\mathrm{G}$ and $0.5 \mathrm{~g}$ streptomycin sulphate base, in $2 \mathrm{ml}$ distilled water. 
the outside of the beakers at the waterline to avoid a high light intensity in the peripheral meniscus which would cause the nauplii to concentrate, with the attendant risk of being stranded on the side of the vessel. The beakers are then placed in constant temperature baths maintained at $20^{\circ} \mathrm{C}$, which have black sides to exclude extraneous light. A 30 watt fluorescent tube $40 \mathrm{~cm}$ above the bath is used to ensure constant light conditions throughout rearing. The tops of the beakers are covered with a black polythene disc so that the larvae are provided with diffused light from the surrounding water in the bath. The $4 \mathrm{l}$ rearing beakers are cleaned with chromic acid at the end of each experiment.

\section{Changing of sea water}

The sea water and food in the rearing vessels are changed three times a week. The contents are poured through a 142 micron pore size nylon mesh filter which retains the larvae but allows the diatoms and most of the faeces to pass through. The empry rearing beakers are thoroughly washed with tap water; $1,000 \mathrm{ml}$ diatoms are then added and the larvae flushed back from the filter cup with sea water at $20^{\circ} \mathrm{C}$, antibiotic added and the volume made up to $3,750 \mathrm{ml}$. At each change a sample of larvae is taken and examined under the microscope for activity and freedom from bacteria; the gut is also examined to verify that they are feeding actively. The larval stage reached by the majority is recorded.

\section{Settlement of cypris stage}

Once stage VI nauplii have appeared in the beakers the subsequent treatment depends upon experimental requirements at the time.

If young adults are required on prepared panels, then ground glass slides, $11 \times$ $4 \times 0.2 \mathrm{~cm}$, are fixed together in pairs with black polythene sheet between them and stood for two or three days in flowing sea water to develop the bacterial films which appear to promote settlement. When cyprids are present, the beakers are cleaned and the larvae are returned by the method described above. Ten pairs of glass panels are placed around the sides of each beaker and a stirrer paddle rotating at $25 \mathrm{revs} / \mathrm{min}$ is used to agitate the water. The stirring appears to stimulate the cyprids to move over the glass surfaces and settle.

When studies are made on survival, settlement and growth rates, panels are not added and the sea water is not stirred. All the settlement then occurs on the sides of the beakers.

After settlement the young adults are kept in flowing sea water or under static conditions.

\section{Identification of the larval stages}

The naupliar stages are distinguished by size and various morphological characteristics; the cypris stage is immediately recognized by its streamlined shape. Table 1 
shows the carapace widths and lengths of Elminius modestus larvae reared at $20^{\circ} \mathrm{C}$ in the laboratory. It was found that for any given rearing temperature the widths and carapace lengths of the nauplii were the best criteria for determining the developmental stage, as the ranges do not overlap.

Table 1

Size of laboratory-reared Elminius modestus larvae

\begin{tabular}{|rccc|}
\hline Stage & $\begin{array}{c}\text { Width } \\
(\mu)\end{array}$ & $\begin{array}{c}\text { Carapace } \\
\text { Length } \\
(\mu)\end{array}$ & $\begin{array}{c}\text { Overall } \\
\text { Length } \\
(\mu)\end{array}$ \\
\hline II & $151-162$ & - & $360-406$ \\
III & $186-197$ & - & $394-452$ \\
IV & $220-255$ & $267-325$ & $418-510$ \\
V & $255-313$ & $325-383$ & $522-603$ \\
VI & $336-406$ & $406-499$ & $568-684$ \\
Cypris & - & $515-576$ & - \\
\hline
\end{tabular}

Sizes of nauplii reared at temperatures other than $20^{\circ} \mathrm{C}$ differ from those given in Table 1 and identification must initially be based on morphology as described by KNIGHT-Jones \& WAUgh (1949).

\section{FACTORS AFFECTING LARVAL DEVELOPMENT \\ Temperature effects}

Experiments have shown that the development of larvae of Elminius modestus and Balanus balanoides is dependent on temperature. Development is slower at lower temperatures but the size of the larvae is increased. This effect on size was observed in nature by CRISP (1962) who reported that the larvae of $B$. balanoides from Arctic waters were larger than those from British waters. However, BARNES \& BARNES (1958) reported that in nature the development time to the cypris stage apparently displayed no regular relationship to temperature, but added that availability of food may "interact with and compensate for temperature effects". They did find that in the laboratory the rate of transition of stage I nauplii of $B$. balanoides to stage II had a temperature coefficient of 2.2. In the present study the quantitative effects of temperature on larval size and rate of development were investigated using $E$. modestus. In these experiments stage I nauplii were divided into two populations kept at $10^{\circ} \pm 1^{\circ} \mathrm{C}$ and $20^{\circ} \pm 1^{\circ} \mathrm{C}$ under identical light and food conditions. The populations were sampled at regular intervals and, as successive larval stages appeared, the lengths and widths of 25 to 30 individuals recorded. The results of two experiments are given in Tables 2 and 3.

The results show that the larvae reared at $10^{\circ} \mathrm{C}$ were larger than those reared at $20^{\circ} \mathrm{C}$, both in overall length, and width and length of the carapace.

When these results are compared with data for planktonic larvae recorded by KNIGHT-JONES \& WAUGH (1949) those reared at $20^{\circ} \mathrm{C}$ are seen to be comparable in 
Table 2

Effect of temperature on size $(\mu)$ of laboratory populations of Elminius modestus larvae (Experiment 1)

\begin{tabular}{|cllccc|}
\hline \multirow{2}{*}{ Stage } & & \multicolumn{2}{c}{$10^{\circ} \mathrm{C}$} & \multicolumn{2}{c|}{$20^{\circ} \mathrm{C}$} \\
& & Mean & Range & Mean & Range \\
\hline II & & \multicolumn{4}{c}{ Not measured } \\
III & Carapace width & 201.7 & $186-209$ & 192.8 & $186-197$ \\
& Overall length & 447.4 & $426-476$ & 430.5 & $406-441$ \\
IV & Carapace width & 244.7 & $232-255$ & 240.8 & $232-255$ \\
& Carapace length & 298.8 & $278-325$ & 300.8 & $278-325$ \\
& Overall length & 489.1 & $441-534$ & 475.7 & $418-499$ \\
VV & Carapace width & 319.2 & $313-336$ & 287.2 & $255-313$ \\
& Carapace length & 382.3 & $360-406$ & 357.6 & $325-383$ \\
& Overall length & 568.0 & $522-603$ & 561.0 & $522-603$ \\
VI & Carapace width & 393.5 & $364-414$ & 371.0 & $336-394$ \\
& Carapace length & 485.8 & $455-515$ & 451.4 & $418-487$ \\
& Overall length & 690.0 & $646-717$ & 606.0 & $568-650$ \\
Cypris & Length & 587.0 & $535-646$ & Not measured \\
& Depth & 245.0 & $212-273$ & & \\
\hline
\end{tabular}

Table 3

Effect of temperature on the size $(\mu)$ of laboratory populations of Elminius modestus larvae (Experiment 2)

\begin{tabular}{|cllllll|}
\hline \multirow{2}{*}{ Stage } & & \multicolumn{2}{c}{$10^{\circ} \mathrm{C}$} & \multicolumn{2}{c|}{$20^{\circ} \mathrm{C}$} \\
& & Mean & Range & Mean & Range \\
\hline \multirow{2}{*}{ II } & Carapace width & 160.3 & $151-162$ & 156.0 & $151-162$ \\
& Overall length & 394.2 & $371-406$ & 381.0 & $360-406$ \\
& Carapace width & 194.3 & $186-209$ & 193.1 & $186-197$ \\
& Overall length & 442.0 & $418-464$ & 430.7 & $394-452$ \\
& Carapace width & 245.6 & $232-255$ & 232.0 & $220-244$ \\
& Carapace length & 306.5 & $290-348$ & 288.9 & $267-313$ \\
& Overall length & 488.0 & $464-510$ & 473.0 & $441-510$ \\
V & Carapace width & 306.2 & $290-325$ & & \\
& Carapace length & 366.5 & $348-406$ & & Not measured \\
& Overall length & 545.0 & $510-590$ & & \\
& VI & Carapace width & 394.0 & $374-414$ & 368.5 & $336-406$ \\
& Carapace length & 473.9 & $434-505$ & 455.0 & $406-499$ \\
& Overall length & 670.0 & $626-727$ & 624.0 & $580-684$ \\
Cypris & Length & \multicolumn{2}{c}{ Not measured } & 545.0 & $515-576$ \\
& Depth & & & 254.5 & $232-273$ \\
\hline
\end{tabular}

size. This is shown in Table 4, which compares the mean widths of larvae reared at $20^{\circ} \mathrm{C}$ with those of planktonic larvae (calculated from the figures given by these authors). Sea water temperatures were not given by KNIGHT-JONES \& WAUGH but it is reasonable to suppose that the temperature was between $17^{\circ}$ and $20^{\circ} \mathrm{C}$ at the time of their recordings. 
Table 4

Size comparison ( $\mu$ ) of planktonic (field) and laboratory-reared larvae of Elminius modestus. Data for stages II to VI represent width measurements; those for the cypris, length measurements. Planktonic field data taken from KNIGHT-JONES \& WAUGH (1949)

\begin{tabular}{|ccccccc|}
\hline $\begin{array}{l}\text { Type of } \\
\text { larvae }\end{array}$ & II & III & $\begin{array}{c}\text { Stage } \\
\text { IV }\end{array}$ & V & VI & Cypris \\
\hline $\begin{array}{l}\text { Planktonic } \\
\text { Laboratory }\end{array}$ & 161.5 & 190.4 & 237.5 & 297.7 & 358.6 & $540-560$ \\
\hline
\end{tabular}

\section{Effect on development time}

In the two experiments described above, the time taken by the larvae to develop to the cypris stage was affected by temperature. In experiment 1 the times were 11 and 21 days at $20^{\circ}$ and $10^{\circ} \mathrm{C}$, respectively. In experiment 2 the times were 17 and 34 days at these temperatures. A comparison of development times at the two temperatures gives a temperature coefficient of approximately 2 which is in reasonable agreement with the value of 2.2 found by BARNES \& BARnEs (1958) for Balanus balanoides.

The two experiments were carried out in 1968 and the times taken to reach the cypris stage at $20^{\circ} \mathrm{C}$ were longer than in 1969 (see section on Yield). However, comparison of the development rates at the two temperatures would appear to be valid, as the conditions of sea water, light and added food were the same at both temperatures.

\section{Effect on survival of laboratory populations}

It was found that survival rates of larval populations were affected by the rearing temperature. Qualitative observations showed that, in general, there is a high or complete mortality at temperatures above $23^{\circ} \mathrm{C}$ with survival increasing at lower values. In Langstone Harbour the sea reaches $20^{\circ} \mathrm{C}$ during the summer and it was decided to use this temperature for rearing the larvae of Elminius modestus in the laboratory.

\section{Effects of light}

The effects on larval development have not yet been fully investigated but results so far indicate that light is necessary for normal development; larvae reared under dark conditions appear to be retarded. Cyprids have been obtained in an experiment under dark conditions where the development time at $16^{\circ} \mathrm{C}$ was 17 davs compared with 12 days for larvae under constant illumination. The significance of the availability of food under these two conditions is uncertain, as the diatoms would presumably multiply under the light conditions, but not in the dark. 
It was found that continuous overhead light produced optimum conditions for uniformity of rearing conditions throughout successive experiments.

\section{Effects of feeding}

During the development of the rearing technique the supplementary food and its concentration were found to be important factors in the growth rate and survival of barnacle larvae. Two diatom species, Skeletonema costatum and Phaeodactylum tricornutum were investigated as supplementary food sources and it was found in agreement with Moyse (1963) that $S$. costatum was the better of the two. Mixtures of the species gave no better results than cultures of $S$. costatum on their own. Their relative food values may explain the difference in the development times of 17 days at $22^{\circ} \mathrm{C}$ recorded by WISELY (1960) for Elminius modestus larvae and 6 days by Moyse (1960) at the same temperature. The former used $P$. tricornutum and the latter S. costatum.

It is possible, therefore, that abnormal development times which occasionally occur in the rearing technique could be caused by a variation in the food cultures. For this reason the diatom cultures are maintained at a relatively constant concentration, and are replaced when they show signs of ageing and 'lagging' growth. They are normally replaced after approximately four weeks.

The concentration of diatoms used in the rearing vessels is relatively high $\left(5 \times 10^{5}\right.$ cells/ml sea water) and is possibly in excess of requirements. Using this concentration, which is very similar to that used by MoYse (1960), the larvae invariably have full guts. Moyse (1963) showed that the growth rate of barnacle larvae is dependent on the amount of food present in the water. FreIberger \& Cologer (1966) successfully used a concentration of approximately $2 \times 10^{5} \mathrm{cells} / \mathrm{ml}$ of the diatom Cyclotella nana for rearing larvae of the barnacles Balanus eburneus, $B$. amphitrite, $B$. trigonus and $B$. improvisus. It would appear, therefore, that for a high and uniform rate of development of barnacle larvae the food concentrations should be high.

\section{YIELD}

Using the technique described large numbers of nauplii and cyprids have been obtained in successive experiments. In experiments during 1969 survivals to the settled stage have been 25 to $50 \%$ of the original population, with large numbers of cyprids normally appearing after approximately seven days and settlement occurring about three days later. Table 5 shows development times to the cypris stage and settlement in eight successive experiments.

In a number of experiments in which settlement on panels was not required, heavy settlements were achieved on the beaker sides under unstirred conditions, yielding up to 4,000 young adults per beaker. Under stirred conditions the majority of cyprids have settled on the beaker sides rather than on the prepared panels. Nevertheless, settlement of significant numbers on glass panels has been achieved, the highest 
being approximately 700 on a $12 \times 7 \times 0.2 \mathrm{~cm}$ slide. The use of the stirring technique in obtaining settlement on panels has proved promising, and the effects of the experimental light conditions are being investigated.

Table 5

Number of days which cyprids of Elminius modestus require to appear and settle in laboratory experiments. Some of the times are less than shown, as observations were not made at weekends: these are marked $<$

\begin{tabular}{|ccc|}
\hline Experiment & Cyprids & Settlement \\
\hline 1 & 7 & $<10$ \\
2 & 8 & $<11$ \\
3 & 9 & $<12$ \\
4 & $?$ & $<12$ \\
5 & $?$ & 8 \\
6 & 6 & 11 \\
7 & 7 & 10 \\
8 & 7 & \\
\hline
\end{tabular}

Young adults obtained from these experiments have been kept alive in the laboratory for over 15 weeks (at time of reporting) and have increased in size up to a diameter of 6 to $8 \mathrm{~mm}$; which is within the normal range of 5 to $10 \mathrm{~mm}$ for adults of Elminius modestus (SOUTHWARd \& CRISP 1963). Over this period adult survival has been approximately $50 \%$ of the original settlement, with the mortalities occurring mainly in the first three weeks. Growth rates of young adults which had settled on beakers were compared under two conditions in the laboratory; (1) static sea water which had food added and changed regularly, as in the rearing technique, and (2) flowing water conditions where ambient temperature sea water was continually passed through the beaker. It was found that the adults grew faster under the flowing conditions even though no supplementary food was added. In an experiment where settlement occurred on the 19 th May the beakers were kept under static conditions with added food until June $23 \mathrm{rd}$. The survival at this time was approximately $50 \%$ and the average size of the adults was $2.8 \mathrm{~mm}$. One beaker was removed and sea water at ambient temperature (initially $16^{\circ} \mathrm{C}$ but later rising to $19^{\circ} \mathrm{C}$ ) was continually passed through it. By July 15 th the average carino-rostral diameter of the adults under flowing conditions was $4.6 \mathrm{~mm}$ compared with $3.1 \mathrm{~mm}$ under static conditions. On the 5th August the adults in the flowing conditions had reached an average diameter of $5.3 \mathrm{~mm}$, whilst those under static conditions averaged $3.3 \mathrm{~mm}$. No significant mortality had occurred under either condition since 23rd June.

\section{DISCUSSION}

A rearing technique was developed in order to provide a continuous supply of larvae and young adult barnacles throughout the year. This aim has been achieved except that in January and February of each year it is difficult to obtain nauplii of Elminius modestus as only a small percentage of adults produce egg-masses. However, 
during this period nauplii are obtained in large numbers from Balanus balanoides and these are reared at $10^{\circ} \mathrm{C}$ according to the technique described above. There have also been times during the normal breeding season of $E$. modestus when it has not been possible to obtain significant numbers of nauplii; the reason for this appears to be a lack of egg-masses in the adults, possibly occasioned by natural mass-liberation of nauplii into the sea. The adults are normally collected from the same area of Langstone Harbour and it is intended at times of low hatchings to sample barnacles from other sites, to determine whether the lack of egg-masses is a localized phenomenon. It was noticed in three experiments when low liberation of nauplii was obtained that they developed slowly and that settlement only occurred after 19, 20 and 21 days; the reason for this is not known.

The growth rate of young adults in the laboratory is dependent on whether they are kept in static or flowing sea water. Although barnacles kept under static conditions were fed with diatoms at a concentration of $2 \times 10^{5}$ cells $/ \mathrm{ml}$ sea water, their growth rates were considerably less than those in untreated flowing sea water. It is difficult to see how feeding activities alone can explain this difference as the adults under static conditions appeared to be actively feeding. It is possible that the adults under static conditions lack some factor(s) present in flowing sea water; this lack could be qualitative or quantitative and the factor(s) might be trace elements or minerals. A greater variety of planktonic species available as food in flowing sea water may explain the faster growth, even though larvae will develop satisfactorily on a unialgal supplementary food.

The method of illumination used allows large numbers of nauplii to be reared in the beakers. This is apparently because the black discs prevent the nauplii from concentrating near the surface and allow relatively even, diffuse light to illuminate the sides of the beakers. The larvae scatter through the beaker and do not concentrate in small volumes as they do under conditions of direct overhead light. Thus maximum use is made by the nauplii of the available food and sea water in the beakers. The densities of nauplii maintained in the rearing beakers (1,250-2,500 individuals/1) are higher than those used by MoYse (1960) who kept the concentrations below 300 nauplii/l, and by FREIBERGER \& COLOGER (1966) who used approximately 265 nauplii/l. Wisely (1960) used very high initial concentrations of between 7,000 and $47,000 / 1$, but reported relatively low yields; this could however have been due to the supplementary food used rather than to overcrowding. The limiting density of nauplii has not yet been investigated.

The development times are comparable with those recorded by MoYse (1960) for Elminius modestus where cyprids first appeared after 6 days at $22^{\circ} \mathrm{C}$ : using the technique described above, large numbers of cyprids are normally present after 7 days at $20^{\circ} \mathrm{C}$. Both techniques use Skeletonema costatum as a food source and the development times are considerably less than those obtained by WISELY (1960) of 15 to 20 days at $19^{\circ}$ to $22^{\circ} \mathrm{C}$ using Pbaeodactylum tricornutum. It would appear therefore, as reported by Moyse (1963), that the food source represents a critical factor in rearing techniques.

The larvae and young adults reared in the laboratory are required for a programme of antifouling studies intended to (1) improve the techniques of evaluating toxics, 
(2) seek a better understanding of the mechanisms controlling metamorphosis and growth of barnacles, and (3) investigate the possibilities of exploiting these biological control mechanisms in an antifouling system. Stage VI nauplii have been used in 1968 and 1969 for testing toxic compounds and it is proposed also to use settling cyprids and newly metamorphosed adults for this purpose. As part of studies on control mechanisms the role of light in larval development was discussed by MoRTLOck (1968) in relation to photoreceptors and neuroendocrine activity, and TIGHE-FORD (1967b) suggested a mechanism for hormone control of breeding through the effects of light and temperature on gland activity and the nervous system. The possible exploitation of biological control mechanisms lies of course in the future and will depend on the nature of such mechanisms.

\section{SUMMARY}

1. A method has been developed for rearing large numbers of the larvae of the barnacle Elminius modestus. At $20^{\circ} \mathrm{C}$, frequent changing of the sea water medium treated with antibiotic allows 25 to $50 \%$ of the original larval population to settle and metamorphose to the adult stage.

2. The diatom Skeletonema costatum has been used as food source in a concentration of $5 \times 10^{5} \mathrm{cells} / \mathrm{ml}$ sea water.

3. The rearing temperature affects not only the rate of development but also the size of the larvae.

4. Constant illumination appears to provide optimum conditions for uniform rearing of larvae in large numbers.

5. Cyprids appear after approximately 7 days and settlement occurs about 3 days later.

6. In the laboratory, young adult barnacles will grow faster in flowing sea water than under static sea water conditions, even though supplementary food is added to the latter.

Acknowledgement. Grateful acknowledgement is made to Mr. D. R. Houghron for reading and commenting on the manuscript.

\section{LITERATURE CITED}

Barnes, H. \& Barnes, M., 1958. The rate of development of Balanus balanoides (L.) larvae. Limnol. Oceanogr. 3, 29-32.

Bassindale, R., 1936. The developmental stages of three English barnacles, Balanus balanoides (Linn.), Chthamalus stellatus (Poli) and Verruca stroemia (O. F. Müller). Proc. zool. Soc. Lond. 106, 57-74.

Costlow, J. D. \& Boокночt, C. G., 1957. Larval development of Balanus eburneus in the laboratory. Biol. Bull. mar. biol. Lab., Woods Hole 112, 313-324.

- 1958. Larval development of Balanus amphitrite var. denticulata BROCH reared in the laboratory. Biol. Bull. mar. biol. Lab., Woods Hole 114, 284-295.

CrISP, D. J., 1962. The planktonic stages of the cirripedia Balanus balanoides (L.) and Balanus balanus (L.) from north-temperate water. Crustaceana 3, 207-221. 
Freiberger, A. \& Cologer, C. P., 1966. Rearing acorn barnacles in the laboratory for marine fouling studies. J. Am. Soc. nav. Engrs. 78, 881-890.

KNIGHT-Jones, E. W. \& WaUGH, G. D., 1949. On the larval development of Elminius modestus larvae. J. mar. biol. Ass. U. K. 27, 413-428.

MorTlock, A. M., 1968. Studies on possible mechanisms for the control of moulting and metamorphosis of barnacle larvae. In: Biodeterioration of materials. Papers presented at the 1st International Biodeterioration Symposium, Southampton 1968. Ed. by A. H. Walters \& J. J. Elphick, Elsevier, Amsterdam.

Moyse, J., 1960. Mass rearing of barnacle cyprids in the laboratory. Nature, Lond. 185, 120.

- 1963. A comparison of the value of various flagellates and diatoms as food for barnacle larvae. J. Cons. int. Explor. Mer. 28, 175-187.

Southward, A. J. \& CRISP, D. J., 1963. Catalogue of main marine fouling organisms. Vol. 1. Barnacles. Organisation for Economic Cooperation and Development, Paris.

Tighe-Ford, D. J., 1967a. A marine laboratory system. Lab. Pract. 16, 1244-1248.

- 1967b. Possible mechanism for the endocrine control of breeding in a cirripede. Nature, Lond. 216, 920-921.

WISELY, B., 1960. Experiments on rearing the barnacle Elminius modestus to the settled stage in the laboratory. Aust. J. mar. Freshrwat. Res. 2, 42-54.

First author's address: D. J. TIGHE-Ford

Exposure Trials Station

Central Dockyard Laboratory

Ferry Road

Southsea, Hants., Great Britain 